\title{
Effect of dapsone on haemoglobin concentration in patients with leprosy
}

\author{
SALLY R BYRD* \& R H GELBER*†† \\ *Gillis W. Long Hansen's Disease Center, Carville, LA 70721, USA \\ and Family Health Foundation of Alviso, 1621 Gold Street, Alviso, \\ CA 95002, USA; $\dagger$ Kuzell Institute, Medical Research Institute, 2200 \\ Webster Street, San Francisco, CA 94115, USA
}

Accepted for publication 12 October 1990

\begin{abstract}
Summary Haemolysis and frank anaemia from dapsone therapy of leprosy has been long recognized. However, the frequency and severity of this side-effect have not been well documented. We report herein a retrospective analysis of the effect of daily dapsone (generally $100 \mathrm{mg} /$ day) on the haemoglobin concentration of 100 leprosy patients undergoing initial chemotherapy. The average haemoglobin was found to fall significantly by almost $2 \mathrm{~g} / \mathrm{dl}$, from $14 \cdot 25 \pm 1 \cdot 27 \mathrm{~g} / \mathrm{dl}$ to a nadir of $12.31 \pm 1 \cdot 61(P<0.001)$. Eighty-three percent of patients had a fall of haemoglobin concentration of $1 \mathrm{~g} / \mathrm{dl}$ or more, while in $16 \%$ of patients the haemoglobin fell $\geqslant 3 \mathrm{~g} / \mathrm{dl}$. Increasing age was found associated with an increased magnitude of dapsone-related haemolysis $(P \leqslant 0 \cdot 004)$. Decreasing the daily dose of dapsone was associated with an increased haemoglobin concentration $(P<0 \cdot 001 \%)$. We have concluded that dapsone commonly results in not only haemolysis but a significant decrease in haemoglobin concentration. This may have serious clinical implications, especially in endemic areas, where, owing to nutrition, malaria, and intestinal parasitism, the haemoglobin concentration is already compromised.
\end{abstract}

\section{Introduction}

Dapsone, which was initially used in the treatment of leprosy in the mid-1940s, ${ }^{1}$ remains the core therapy for this disease, as well as for certain noninfectious dermatoses. Although haemolysis has been frequently cited as one of the chief side-effects of this drug, ${ }^{2-4}$ the actual magnitude of this haemolysis and its clinical significance, particularly at doses currently used to treat leprosy, have not been well documented. We have therefore attempted to review a series of our own patients treated with dapsone to determine the incidence and degree of haemoglobin decrease and its association with dapsone dosage.

$\ddagger$ Reprint requests. 


\section{Materials and methods}

The records of all new patients seen at the Regional Hansen's Disease Program in San Francisco between 1983 and 1988 were reviewed, and the first 100 patients who did not have excluding criteria were selected to be considered in the analyses. Patients were excluded from the study if they presented with significant anaemia before receiving dapsone or if they were already taking dapsone prior to their first clinical visit. Patients with inadequate follow-up were also not considered in this analysis. Patients weighing less than $45.5 \mathrm{~kg}$ generally received $50 \mathrm{mg}$ dapsone per day and those weighing $45.5 \mathrm{~kg}$ or more received $100 \mathrm{mg}$ per day on their initial visit. A complete blood count (CBC) and general chemistry panel were obtained on every patient prior to the administration of dapsone and in most cases (96/100) a G6PD level was also determined. G6PD levels were determined by measurement of the rate of production of a product of its catalytic activity, NADPH, at its peak ultraviolet absorbance, $340 \mathrm{~nm}$ (normal values being 8-18 U/g hgb, mean \pm 2 sd. $)^{5}$ Patients were seen in follow-up generally within one month, and thereafter at intervals between one and six months. $\mathrm{CBC}$ and chemistry panels were usually obtained at each visit. Those patients showing significant drops in their haemoglobin/haematocrit values often had reticulocyte counts and haptoglobin levels checked, and the dapsone dose was frequently reduced. Significant haemoglobin decreases occurring during Type II erythema nodosum leprosum (ENL) reactions or at times of intercurrent disease contributing to anaemia were not included in the analyses.

Of the one hundred patients analysed, sixty-three were male and thirty-seven were female. Their mean age was $37 \cdot 4$ years, with a range of 12 to 79 years. Twenty-five of these patients had lepromatous leprosy (LL), twenty had borderline lepromatous disease (BL), and fifty-four had borderline tuberculoid disease (BT). A breakdown by ethnicity revealed 37 Filipinos, 32 Southeast Asians, 18 Mexicans, 4 Indians or Pakistanis, 5 Pacific Islanders, 1 African, 1 Palestinian, and 1 of mixed ethnic background among the evaluated patients.

Statistical analysis was done mostly by the paired $t$ test. The relationship of fall in haemoglobin and age was analysed by standard tests. ${ }^{6,7}$

\section{Results}

Of the 96 patients who had G6PD levels measured, 94 had normal levels and in two it was decreased. In one of the patients, a 27-year-old Filipino male, with a low G6PD level ( 0.4 $\mathrm{U} / \mathrm{g} \mathrm{hgb}$ ) there was a drop in haemoglobin concentration from $15.6 \mathrm{~g} / \mathrm{dl}$ to $7 \cdot 2 \mathrm{~g} / \mathrm{dl}$ six days after initiation of dapsone at $100 \mathrm{mg} /$ day. This was the most marked decrease in haemoglobin seen in the 100 patients analysed for this study. The other patient, a 36-yearold Vietnamese male, with a low G6PD level $(0.8 \mathrm{U} / \mathrm{g} \mathrm{hgb})$ had a $2.9 \mathrm{~g} / \mathrm{dl}$ drop in haemoglobin two weeks after initiating dapsone at $100 \mathrm{mg} / \mathrm{day}$. Both had their dapsone stopped, whereafter their haemoglobin concentrations rose back to pretreatment levels.

For assessment of haemoglobin fall in general, the data was analysed in two different manners. In the first analysis haemoglobin nadir was used and considered to be significant if the fall between pretreatment levels and nadir was $\geqslant 1 \mathrm{~g} / \mathrm{dl}$. The time between start of dapsone and nadir haemoglobin was then calculated. In the second analysis, to control 
Table 1. Breakdown of patients by sex and age

\begin{tabular}{lcccc}
\hline $\begin{array}{l}\text { Fall in hgb* } \\
(\mathrm{g} / \mathrm{dl})\end{array}$ & Patients & $\begin{array}{c}\text { Male } \\
(\% \text { of males })\end{array}$ & $\begin{array}{c}\text { Female } \\
(\% \text { of females })\end{array}$ & $\begin{array}{c}\text { Mean age } \\
( \pm \mathrm{SD})\end{array}$ \\
\hline$<1 \cdot 0$ & 17 & $12(20 \%)$ & $5(13 \%)$ & $30 \cdot 9 \pm 15 \cdot 8$ \\
$1 \cdot 0-1 \cdot 9$ & 31 & $17(28 \%)$ & $14(36 \%)$ & $34 \cdot 6 \pm 15 \cdot 7$ \\
$2 \cdot 0-2 \cdot 9$ & 36 & $19(31 \%)$ & $17(43 \%)$ & $37 \cdot 5 \pm 18 \cdot 7$ \\
$>3 \cdot 0$ & 16 & $13(21 \%)$ & $3(8 \%)$ & $45 \cdot 9 \pm 20 \cdot 7$ \\
\hline
\end{tabular}

* Baseline haemoglobin minus nadir haemoglobin.

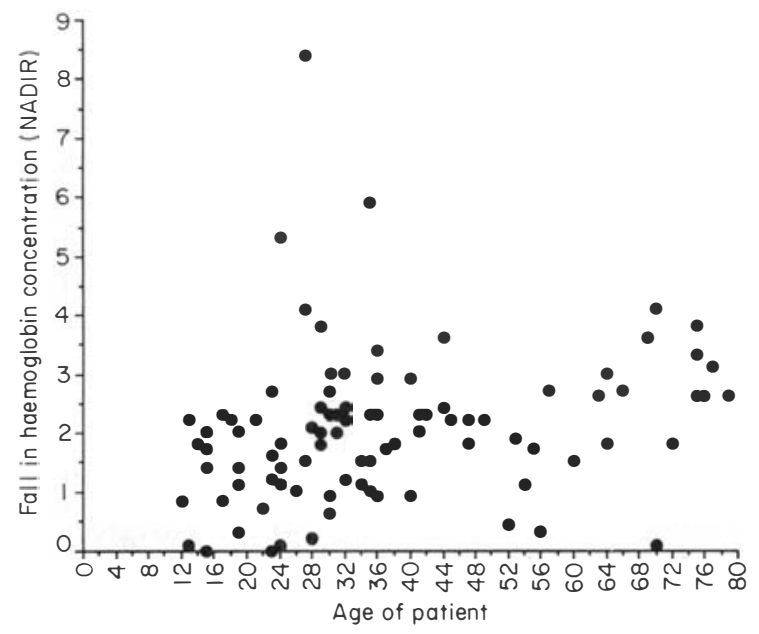

Figure 1. Fall in nadir haemoglobin concentration.

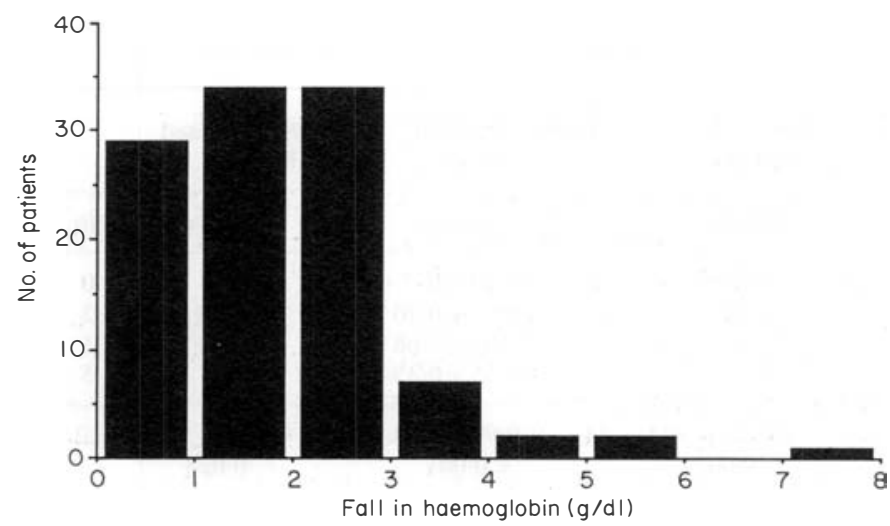

Figure 2. Fall in nadir haemoglobin concentration. 
better for selection bias, an arbitrary time interval of one month was chosen and if data at this time was not available the results from the nearest visit were used.

When assessing haemoglobin nadir (see Table 1 and Figures 1 and 2), we found that the mean haemoglobin concentration for all patients fell from $14 \cdot 25 \pm 1 \cdot 27 \mathrm{~g} / \mathrm{dl}$ to $12 \cdot 31 \pm 1 \cdot 61(P<0.001)$. Eighty-three percent had a fall in haemoglobin concentration of $1 \mathrm{~g} / \mathrm{dl}$ or more. Of these, $31 \%$ had a haemoglobin fall between 1.0 and $1.9,36 \%$ between $2 \cdot 0$ and $2 \cdot 9$, and $16 \%$ fell more than $3 \mathrm{~g} / \mathrm{dl}$. Analysis of the fall in haemoglobin nadir at intervals of $0.5 \mathrm{~g} / \mathrm{dl}$ haemoglobin for the entire population studied demonstrates that the distribution of that fall appears unimodel (see Figures $1 \& 2$ ). The average time to haemoglobin nadir was $16 \cdot 8 \pm 27 \cdot 4$ weeks or approximately four months. (A few patients had nadir haemoglobins at one-to-two years after starting dapsone, resulting in the large standard deviation observed.) While a greater percentage of females ( $87 \%$ vs $80 \%$ male) had significant $(\geqslant 1 \mathrm{~g} / \mathrm{dl})$ decreases in haemoglobin, a higher percentage of men $(21 \% \mathrm{vs}$ $8 \%$ female) had more marked $(\geqslant 3 \mathrm{~g} / \mathrm{dl}$ ) haemoglobin falls. Increasing age was found associated with an increase in dapsone haemolysis (Pearson correlation coefficient $(r)$ $0 \cdot 287, P=0.004$ and Kendall correlation coefficient $0 \cdot 235, P=0 \cdot 008$ ).

When confining the analysis of haemoglobin drop essentially to the first month or so (mean 4.6 weeks \pm 2.4 ), $72 \%$ of patients had significant drops of $1 \mathrm{~g} / \mathrm{dl}$ or more. Of the abnormalities, 33\% dropped between 1 and $1.9 \mathrm{~g} / \mathrm{dl}, 29 \%$ between 2.0 and $2.9 \mathrm{~g} / \mathrm{dl}$, and $10 \%$ had decreases of $3 \mathrm{~g} / \mathrm{dl}$ or more. Again, a higher percentage of men ( $13 \% \mathrm{vs} 5 \%)$ had the most marked haemoglobin declines. The overall mean haemoglobin concentration fell from $14.28 \pm 1.64 \mathrm{~g} / \mathrm{dl}$ to $12.66 \pm 1.66 \mathrm{~g} / \mathrm{dl}(P<0.001)$.

Nineteen patients had haptoglobin levels measured during the time period investigated. Of these, $12(63 \%)$ had levels $<50 \mathrm{mg} / \mathrm{dl}, 3(16 \%)$ were in the $50-100 \mathrm{mg} / \mathrm{dl}$ range, and $4(21 \%)$ had normal levels. While low levels were felt to indicate ongoing haemolysis, haptoglobin levels did not always correlate well with the degree of haemoglobin drop. Five of the patients with normal or only mild declines in haptoglobin had haemoglobin drops of $2 \mathrm{~g} / \mathrm{dl}$ or greater, while 4 of the patients with haptoglobins of $<50 \mathrm{mg} / \mathrm{dl}$ had haemoglobin drops of $<2 \mathrm{~g} / \mathrm{dl}$.

Twenty patients also had reticulocyte counts measured, and they were found to be elevated $(>1.5 \%)$ in $17(85 \%)$ of them. While, in general, there was no good correlation

Table 2. Effect of changing dapsone dose on haemoglobin recovery

\begin{tabular}{|c|c|c|c|c|c|c|c|c|}
\hline \multirow{2}{*}{$\begin{array}{l}\text { Drop in } \\
\text { hgb at } 1 \\
\text { month } \\
(\mathrm{g} / \mathrm{dl})\end{array}$} & \multicolumn{2}{|c|}{$\begin{array}{l}\text { No change } \\
\text { in DDS }\end{array}$} & \multicolumn{2}{|c|}{$\begin{array}{c}\text { DDS decreased } \\
\text { by } 50 \%\end{array}$} & \multicolumn{2}{|c|}{$\begin{array}{c}\text { DDS decreased } \\
\text { by } 75 \%\end{array}$} & \multicolumn{2}{|r|}{$\begin{array}{c}\text { DDS } \\
\text { stopped }\end{array}$} \\
\hline & No. & Recovery* & No. & Recovery & No. & Recovery & No. & Recovery \\
\hline$<1 \cdot 0$ & 26 & $+0.09 \pm 0.64$ & 2 & $+0 \cdot 20 \pm 0$ & 0 & - & 0 & - \\
\hline $1-1.9$ & 21 & $+0.32 \pm 0.49$ & 8 & $+0.81 \pm 0.70$ & 1 & $+1 \cdot 70 \pm 0$ & 2 & $+1.8 \pm 0.28$ \\
\hline $2-2 \cdot 9$ & 10 & $+0.46 \pm 0.51$ & 12 & $+1.01 \pm 0.68$ & 2 & $+1.70 \pm 0.71$ & 5 & $+2.98 \pm 1.0$ \\
\hline$\geq 3 \cdot 0$ & 3 & $+0.87 \pm 1.3$ & 2 & $+1.55 \pm 0.35$ & 0 & - & 5 & $+4 \cdot 36 \pm 1.88$ \\
\hline $\begin{array}{l}\text { Total } \\
P \text { value }\end{array}$ & 60 & $\begin{array}{c}+0.27 \pm 0.63 \\
0.002\end{array}$ & 24 & $\begin{array}{c}+0.92 \pm 0.68 \\
<0.001\end{array}$ & 3 & $\begin{array}{c}+1.70 \pm 0.50 \\
0.028\end{array}$ & 12 & $\begin{array}{c}+3 \cdot 36 \pm 1 \cdot 62 \\
<0.001\end{array}$ \\
\hline
\end{tabular}

${ }^{*}$ Recovery $=($ average haemoglobin $\mathrm{g} / \mathrm{dl}$ after dapsone change $)-($ haemoglobin $\mathrm{g} / \mathrm{dl}$ at 1 month) \pm S.D. 
between the degree of reticulocytosis and the drop in haemoglobin, the patient with the greatest reticulocyte response $(21 \%)$ was the one with G6PD deficiency and the most dramatic fall in haemoglobin.

Among the 100 patients studied, 40 were described as having poikilocytosis or anisocytosis on blood smear after the initiation of dapsone. Elevations in total bilirubin and $\mathrm{LDH}$ were seen in $25 \%$ and $27 \%$ of patients respectively although the abnormalities were usually mild.

In the last part of this analysis, an attempt was made to determine what effect
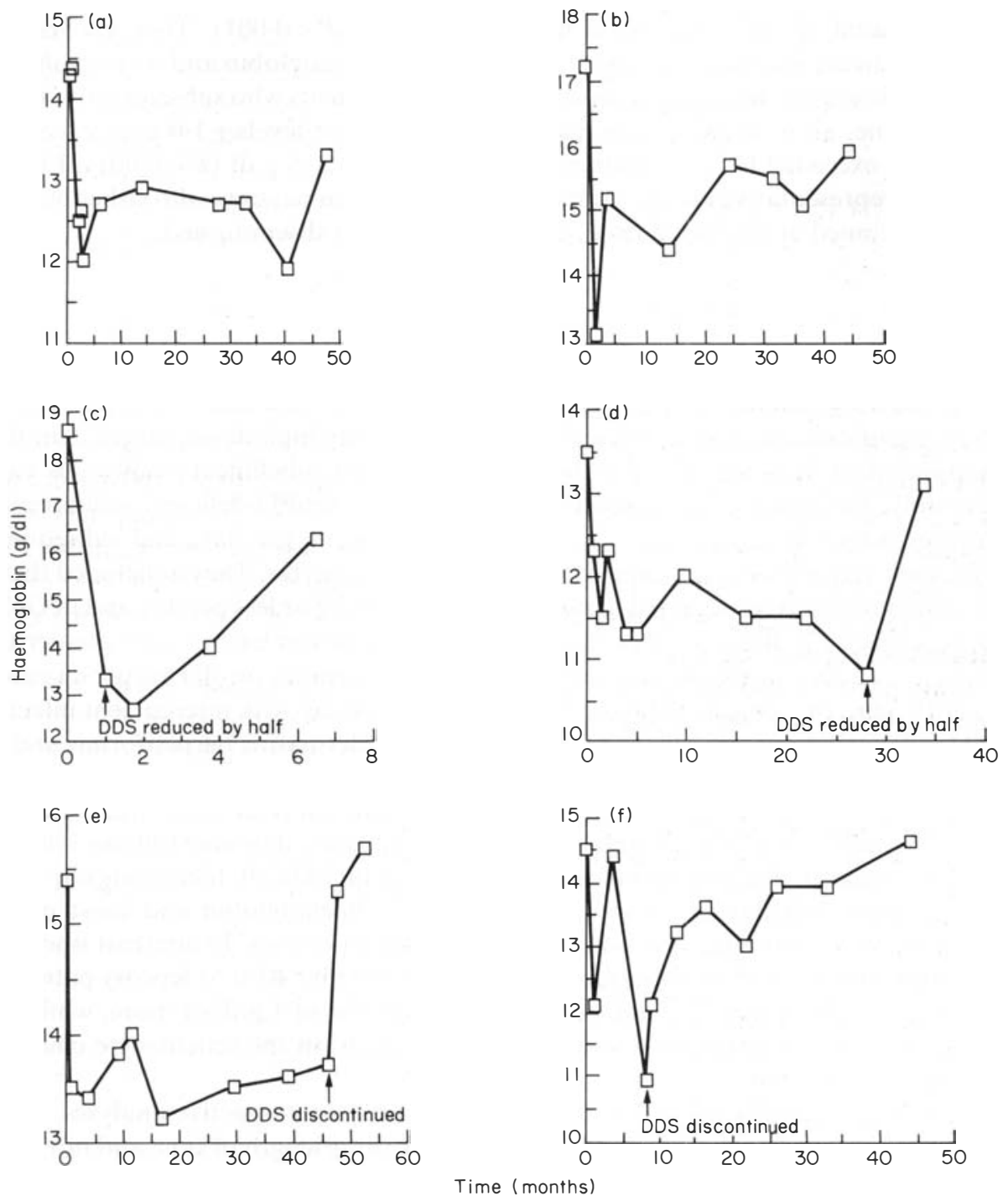

Figure 3. Changes in haemoglobin level over time with dapsone. (a) and (b), no change in dapsone dose; (c) and (d), decrease in dapsone dose by $50 \%$; (e) and (f), discontinuation of dapsone. 
alterations in dapsone dose would have on subsequent haemoglobin levels. The one month (or subsequent visit) haemoglobin level was used as the initial reference point. If no change in dapsone dosage was made, all subsequent haemoglobin levels on follow-up visits were averaged and compared to the one-month level to see whether there had been any recovery or overall further decline. When there was a lowering or discontinuation of dapsone, all haemoglobin levels greater than one month after the change were averaged and again compared to the one-month value. (Haemoglobin levels were considered to have returned to normal if they were $<1 \mathrm{gm} \%$ lower than pretreatment levels.) As can be seen in Table 2, on average there was some increase in haemoglobin levels even in patients who did not have their dapsone dose changed $(P=0.002)$, while patients who had their dapsone reduced by $50 \%$ had more marked recovery $(P<0 \cdot 001)$. This recovery was greatest in patients who had the largest initial drop in haemoglobin and was significantly enhanced by lowering the dapsone dose. Among those patients who subsequently stopped taking dapsone, all returned to pretreatment haemoglobin levels $\pm 1 \cdot 0 \mathrm{~g} / \mathrm{dl}$, except one patient, who exceeded his pretreatment haemoglobin by $1.5 \mathrm{~g} / \mathrm{dl}(P<0.001)$. Figure 3 shows some representative curves for haemoglobin levels in patients who either had their dapsone continued at the initial dose, reduced by half, or discontinued.

\section{Discussion}

Some of the early studies of dapsone-induced haemolysis and anaemia suggested that clinically significant haemolysis occurred only at relatively high doses, larger than those normally used to treat leprosy, and that even findings of subclinical haemolysis varied considerably. DeGowin et $\mathrm{al}^{3}{ }^{3}$ studied 10 normal and 5 G6PD-deficient volunteers, to whom they administered between 25 and $300 \mathrm{mg}$ dapsone per day, and subsequently assessed their red cell survival using $51 \mathrm{Cr}$-labelled erythrocytes. They concluded that no or only slight haemolysis occurred in normals taking $100 \mathrm{mg}$ or less per day and in G6PDdeficient subjects on $50 \mathrm{mg}$ or less. Furthermore, decreases in haematocrit greater than those due to random variation were only found in three normals on $300 \mathrm{mg}$ per day and in two G6PD-deficient subjects either on $200 \mathrm{mg}$ /day or $100 \mathrm{mg}$ with intercurrent infection. Similarly, Pengelly ${ }^{8}$ reported that of four patients with dermatitis herpetiformis and one normal subject given between 50 and $150 \mathrm{mg}$ of dapsone daily, none developed significant anaemia. However, all were found to have reduced RBC survival. In a larger study, ${ }^{2} 43$ patients with dermatitis herpetiformis on 50-300 mg dapsone/day were followed. Red cell survival was measured in 10 patients and found to be reduced in all. Increasing dapsone to $150 \mathrm{mg}$ or more per day invariably caused a fall in haemoglobin and most patients receiving $50 \mathrm{mg}$ or more per day had a persistent reticulocytosis. In contrast one study ${ }^{9}$ shows results similar to those reported herein; they found that 40 of 51 leprosy patients on $50-100 \mathrm{mg}$ of dapsone per day had a drop in haemoglobin of $1 \mathrm{~g} / \mathrm{dl}$ or more, while 17 of them had evidence of haemolysis suggested by elevations in the reticulocyte count and indirect serum bilirubin.

Our study exemplifies some of the problems of many retrospective analyses. Not all patients were checked at the same intervals or for the same length of time and not all had corroborative tests. Furthermore, no consistent documentation of missed medication doses or intercurrent infection, which might affect haemoglobin levels, was routinely made. However, with attempts to control for this, the study appears to demonstrate that 
significant falls in haemoglobin occur in a high percentage $(83 \%$ or $72 \%$, according to the analytic method used) of patients on doses of dapsone previously felt to cause little clinically significant anaemia.

In this present study, while only a small number of patients had haptoglobin or reticulocyte counts measured, a high percentage ( $79 \%$ and $85 \%$ respectively) of those who did had abnormal levels, re-emphasizing haemolysis as the probable cause for the haemoglobin decline seen with dapsone administration. G6PD deficiency has been considered a major risk factor for dapsone-caused haemolysis. ${ }^{10}$ Certainly, one of our patients with G6PD deficiency had a dramatic $(8.4 \mathrm{~g} / \mathrm{dl})$ haemoglobin fall in just six days. The only other patient with G6PD deficiency had a more modest $(2.9 \mathrm{~g} / \mathrm{dl})$ fall in haemoglobin, while four male patients with no demonstrable G6PD deficiency (G6PD values: $10 \cdot 4,11 \cdot 3,12 \cdot 5$, and $14 \cdot 7 \mathrm{U} / \mathrm{g} \mathrm{Hgb}$ ) had falls in haemoglobin greater than $4 \mathrm{~g} / \mathrm{dl}$ within the first month, indicating that other factors probably contribute to the risk of haemolysis (anaemia) with dapsone.

Additionally, the greater recovery of haemoglobin levels with progressively decreasing doses of dapsone points out the dose dependency for haemolysis by dapsone. It also appears, however, that if patients are maintained on dapsone at the original dose, there is some degree of bone marrow compensation, so that the final haemoglobin levels are somewhat higher than the initial drop. Drops in haemoglobin much later during treatment might be explained by intercurrent infections or mild undocumented lepra reactions which might nevertheless suppress the bone marrow's ability to compensate the ongoing haemolysis.

In summary, 100 patients from the San Francisco Hansen's Disease Program were retrospectively evaluated for the effect of dapsone on haemoglobin levels. It was found that a fairly high percentage $(72-83 \%)$ of patients treated with dapsone at $100 \mathrm{mg}$ per day or less had falls in their haemoglobin concentrations of $1 \mathrm{~g} / \mathrm{dl}$ or more. While some compensation and reversal of this drop was evident if patients continued on dapsone, the anaemia was found to be both dose- and age-related, and recovery was more marked if the dose of dapsone was reduced. One patient with G6PD deficiency had a dramatic $(8 \cdot 4 \mathrm{~g} / \mathrm{dl})$ fall in his haemoglobin level necessitating not only in the drug being discontinued but also being given a red cell transfusion.

\section{References}

1 Lowe J, Davey T. 4 Years' experience of sulphone treatment of leprosy. Trans Roy Soc Trop Med \& Hyg, 1951; 44: 635-63.

2 Cream JJ, Scott TL. Anaemia in dermatitis herpetiformis. The role of dapsone induced haemolysis and malabsorption. Br J Dermatol, 1970; 82: 333-42.

${ }^{3}$ DeGowin RL, Eppes RB, Powell R. et al. The haemolytic effects of diphenylsulfone (DDS) in normal subjects and those with glucose-6-phosphate dehydrogenase deficiency. Bull WHO, 1966; 35: 165-79.

${ }^{4}$ Smith RS, Alexander S. Heinz-body anemia due to dapsone. Br Med J, 1959; 1: 625-7.

${ }^{5}$ Fairbanks V, Klee G. Biochemical Aspects of Hematology, In: Textbook of Clinical Chemistry, Tietz N. (ed.), Philadelphia: W B Saunders, 1986, 1498-1588.

6 Kendall MG. Rank Correlation Methods. London: Griffin, 1962.

7 Pfaffenberger RL, Patterson JH. Statistical Methods. Homewood, I11., USA, Richard Irwin, Inc., 1987, 687-8.

8 Pengelly GDR. Dapsone-induced haemolysis. Br Med J, 1963; 2: 552-64.

9 Puavilai S. et al. Incidence of anemia in leprosy patients treated with dapsone. J Med Assoc Thailand, 1984; 67: 404-7.

10 deGowin RL. A review of therapeutic and hemolytic effects of dapsone. Arch Intern Med, 1967; 120: $242-8$. 


\title{
L'effet de dapsone sur la concentration d'hémoglobine dans les patients lépreux
}

\author{
Sally R Byrd et R H Gelber
}

Sommaire Dupuis longtemps l'hémolyse et l'anémie s'associent au thérapie de dapsone pour le traitement de la lèpre. Néanmoins, la fréquence et la sévérité de cet effet secondaire n'ont pas été bien documentées. Ici, on rend compte d'une analyse rétrospective de l'effet des doses quotidiennes de dapsone (généralement de $100 \mathrm{mg} / \mathrm{jour}$ ) sur la concentration d'hémoglobine chez 100 patients de lèpre qui étaient en train de suivre les premières étapes de chimiothérapie. La concentration moyenne d'hémoglobine a subi une baisse importante de preque $2 \mathrm{~g} / \mathrm{dl}$, de $14,25 \pm 1,27 \mathrm{~g} / \mathrm{dl}$ jusqu'à un minimum de $12,31 \pm 1,61(\mathrm{p}<0,001)$. Quatre-vingts treize pourcent des patients ont subi une baisse dans la concentration d'hémoglobine de $1 \mathrm{~g} / \mathrm{dl}$ ou plus, tandis que chez $16 \%$ de patients, le niveau a baissé $>3 \mathrm{~g} / \mathrm{dl}$. On a trouvé une corrélation entre l'âge et l'hémolyse attribuable à la dapsone $(\mathrm{p}<0,004)$. Une baisse dans la concentration quotidienne de dapsone était liée à une hausse dans la concentration d'hémoglobine $(\mathrm{p}<0,001 \%$ ). On a conclu qu'en général, la dapsone produit non seulement l'hémolyse, mais aussi une baisse importante dans les niveaux d'hémoglobine. Cela peut avoir des graves implications médicales, surtout dans des zones endémiques, où la concentration d'hémoglobine se voit dé jà mánacée à cause de la nutrition, le paludisme, et le parasitisme intestinal.

\section{El efecto de la dapsona sobre la concentración de hemoglobina en pacientes de lepra}

\author{
S R BYRD y R H Gelber
}

Resumen Hace ya tiempo que se'asocia la hemólisis y la anemia a la terapia de dapsona para el tratamiento de la lepra, aunque la gravedad y la frecuencia de este ef ecto secundario no estan bien documentadas. Presentamos aquí los resultados de un análisis retrospectivo del ef ecto de dosis diarias de dapsona (por lo general de $100 \mathrm{mg} /$ día) sobre la concentración de hemoglobina en 100 pacientes de lepra en etapas iniciales de quimioterapia. La concentración media de hemoglobina sufrió una ba ja importante de casi $2 \mathrm{~g} / \mathrm{dl}$, de $14,25 \pm 1,27 \mathrm{~g} / \mathrm{dl}$ a un nadir de $12,31 \pm 1,61(\mathrm{p}<0,001)$. El ochenta y tres por ciento de los pacientes sufrió una baja en la concentración de hemoglobina de $1 \mathrm{~g} / \mathrm{dl}$ o más, mientras que en un $16 \%$ de los pacientes sufrió una baja igual o superior a $3 \mathrm{~g} / \mathrm{dl}$. Se observó una correlación entre la edad y el aumento de hemólisis debido a la dapsona $(\mathrm{p} \leq 0,004)$. Una reducción en la dosis diaria de dapsona se asoció a un aumento en la concentración de hemoglobina $(\mathrm{p}<0,001 \%)$. Hemos llegado a la conclusión de que, en general, la dapsona no solo produce hemólisis sino tambien una reducción importante en la concentración de hemoglobina. Esto puede tener consecuencias importantes, sobre todo en zonas endémicas donde, debido a la alimentación, a la malaria y al parasitismo intestinal, la concentración de hemoglobina ya se ve amenazada. 